Idarotuna, Vol. 1. No. 1. Oktober 2018

\title{
IMPLEMENTASI NILAI-NILAI DAKWAH DALAM MANAJEMEN PEMASARAN DI BANK BNI SYARIAH PEKANBARU
}

\author{
Syahril Romli, Arwan, dan Muhammad Irham \\ Fakultas Dakwah dan Komunikasi UIN Suska Riau \\ Email: syahrilromli@uin-suska.ac.id
}

\begin{abstract}
Abstrak
Penelitian ini dilatar belakangi oleh persoalan perbankan syariah sebagai lembaga ekonomi syariah dalam mengimplementasikan nilai-nilai dakwah dalam aktivitasnya. Terutama aktivitas manajemen pemasaran belum diimplementasikan secara maksimal. Implementasi nilai-nilai dakwah adalah penerapan nilai-nilai ajaran Islam yang terkandung dalam al-Qur'an dan al-hadits. Permasalahan dalam penelitian ini adalah bagaimana implementasi nila-nilai dakwah dalam manajemen pemasaran di Bank BNI Syariah Pekanbaru. Tujuan penelitian ini adalah untuk mengetahui implementasi nila-nilai dakwah dalam manajemen pemasaran di Bank BNI Syariah Pekanbaru. Subjek penelitian ini adalah Kepala bagian Pemasaran Bank BNI Syariah Pekanbaru dan beberapa orang karyawannya serta ditambah beberapa orang Nasabah. Selanjutnya yang menjadi objek dalam penelitian ini adalah implementasi nilainilai dakwah dalam manajemen pemasaran. Jenis penelitian ini adalah deskriptif menggunakan pendekatan kualitatif. Informan penelitian berjumlah 6 orang. Pengumpulan data dilakukan melalui observasi, wawancara dan dokumentasi yang kemudian hasil data tersebut dianalisis secara deskriptif kulaitatif. Penelitian ini menemukan bahwa Implementasi nila-nilai dakwah dalam manajemen pemasaran di Bank BNI Syariah Pekanbaru telah mengacu kepada nilai-nilai dakwah yang terkandung dalam aktivitas manajemen pemasaran syariah berdasarkan konsep keteladanan dari sifat Rasulullah SAW yaitu shiddiq, fathanah, amanah, tabligh dan istiqamah. Kelima nilai tersebut telah diimplementasikan dalam setiap aktivitas manajemen pemasaran di Bank BNI Syariah Pekanbaru, baik dalam proses pemilihan produk, penentuan harga, distribusi maupun proses promosi.
\end{abstract}

Keywords: Impementasi Nilai-nilai Dakwah, Manajemen Pemasaran 


\section{Pendahuluan}

Memperoleh keuntungan merupakan tujuan utama berdirinya suatu perusahaan ataupun badan usaha, baik badan usaha yang berbentuk Perseoran Terbatas (PT), Yayasan maupun bentuk-bentuk badan usaha lainnya. Sebab keuntungan yang diperoleh tidak hanya digunakan untuk membiayai operasi perusahaan, seperti membayar gaji serta biaya-biaya lainnya, tetapi juga untuk perkembangan perusahaan melalui berbagai kegiatan dimasa yang akan datang.

Pada praktiknya tidak semua badan usaha yang didirikan memperoleh keuntungan seperti yang diharapkan. Tidak sedikit badan usaha yang mati sebelum berkembang karena mengalami kerugian secara terus menerus. Dampak kerugian yang diderita oleh suatu badan usaha bukan hanya membangkrutkan perusahaan, tetapi juga mengakibatkan terjadi Pemutusan Hubungan Kerja (PHK) terhadap karyawannya. Supaya badan usaha tidak menderita kerugian atau dengan kata lain harus memperoleh keuntungan seperti yang ditargetkan, perlu mengelolanya secara profesional. Tanpa pengelolaaan yang profesional jangan diharapkan perusahaan akan dapat memperoleh keuntungan seperti yang diharapkan. Kegiatan mengelola inilah yang kita kenal dengan istilah manajemen. Pengertian manajemen di samping mengelola atau mengatur suatu kegiatan atau usaha adalah mencapai tujuan melalui orang lain. Artinya, tidak ada suatu tujuan yang dicapai tanpa bantuan orang lain. ${ }^{1}$

Selanjutnya keberhasilan suatu perusahaan dalam mencapai tujuan dan sasaran sangat dipengaruhi oleh kemampuan memasarkan produknya. Tujuan perusahaaan untuk dapat menjamin kelangsungan hidupnya, berkembang dan mampu bersaing, terjadi apabila perusahaan dapat menjual produknya dengan harga yang menguntungkan pada tingkat kuantitas yang diharapkan serta mampu mengatasi

\footnotetext{
${ }^{1}$ Kasmir, Manajemen Perbankan ( Jakarta : Rajawali Pers, 2012), hlm. 3.
}

tantangan dari para pesaing dalam
pemasaran. $^{2}$

Pemasaran diartikan sebagai usaha untuk menyediakan dan menyampaikan barang dan jasa yang tepat kepada orangorang yang tepat, tempat, waktu serta harga yang tepat dengan promosi dan komunikasi yang tepat. Alex S. Nitisimito menyebutkan bahwa pemasaran bagaikan jantung sebuah perusahaan. Jika pemasaran suatu perusahaan sampai berhenti karena barang/jasa yang dijualnya tidak laku terjual maka perusahaan tersebut akan mengalami kesulitan bahkan kegagalan, bila pemasaran berhenti maka berhentilah semua kegiatan perusahaan. $^{3}$

Sementara itu perkembangan dunia usaha dewasa ini ditandai dengan makin tajamnya persaingan. Oleh Karen itu peranan pemasaran semakin penting dan merupakan ujung tombak setiap perusahaaan. Melihat betapa pentingnya aktivitas pemasaran dalam sebuah perusahaan terutama perusahaan bisnis, maka perlu adanya pengaturan atau pengelolaan yang sistematis terhadap aktivitas pemasaran. Seiring dengan perkembangan dunia yang begitu pesat, diikuti dengan kemajuan teknologi informasi dan telekomunikasi yang berkembang dalam hitungan detik, maka berimbas terhadap perkembangan dunia ekonomi. Hal ini ditandai dengan munculnya berbagai lembaga yang bergerak dalam bidang ekonomi khusunya lembaga keuangan baik yang bersifat perbankan maupun non perbankan.

Perbankan Syariah sebagai suatu lembaga keuangan yang menawarkan produk berupa jasa kepada khalayak ramai juga membutuhkan manajemen pemasaran yang professional. Manajemen pemasaran sebagai salah satu aktivitas yang sangat penting dalam perbankan Syariah harus pula

\footnotetext{
${ }^{2}$ Sofjan Assauri, Manajemen Pemasaran : Dasar, Konsep dan Strategi ( Jakarta : PT. Raja Grafindo Persada, 1996), hlm. 57.

${ }^{3}$ Alex S. Nitisemito, 1.647 Dialog Bisnis dan Manajemen (Jakarta : Ghalia Indonesia, 2001), hlm. 11.
} 
berlandaskan pada prinsip-prinsip syariah yang bersumber dari al-Qur'an dan al-Hadis dalam pelaksanaannya. Timbul pertanyaan dalam diri kita, apakah lembaga-lembaga keuangan yang berlebelkan syariah seperti perbankan syariah telah menerapkan nilainilai Islam dalam aktivitas manajemen pemasaran, ataukah hanya sekedar ingin mendapatkan tanggapan positif dari kalangan muslim karena berlebelkan syariah?

Agar nilai-nilai Islam dapat diterapkan dalam setiap aktivitas pada lembaga ekonomi syariah perlu adanya aktivitas keagamaan yang secara langsung digunakan untuk mensosialisasikan ajaran Islam. Menyebarkan nilai-nilai ajaran islam agar dapat diterapkan dalam segala aktivitas pada lembaga ekonomi Syaria. Aktivitas tersebut adalah aktivitas dakwah. Aktivitas ini dilakukan baik melalui lisan, tulisan, maupun perbuatan nyata. Dakwah merupakan upaya untuk mengajak, mendorong dan memotivasi orang agar berbuat baik dan mengikuti jalan petunjuk, dan melakukan amar ma'ruf nahi munkar dengan tujuan mendapatkan kesuksesan dan kebahagiaan di dunia dan akhirat. ${ }^{4}$ Aktivitas Dakwah Islam bertujuan untuk menyebarkan nilai-nilai ajaran Islam yang terkandung dalam al-Qur'an dan alSunnah serta meningkatkan pemahaman keagamaan dalam berbagai aspek ajarannya agar diaktualisasikan dalam bersikap, berfikir dan bertindak. ${ }^{5}$

Dakwah ekonomi adalah aktivitas dakwah yang dilakukan umat Islam yang berusaha mengimplementasikan ajaran Islam yang berhubungan dengan proses-proses ekonomi guna peningkatan kesejahteraan umat Islam. ${ }^{6}$ Dakwah Ekonomi bertujuan agar nilai-nilai dakwah yang berisikan nilainilai ajaran Islam yang bersumber dari alQur'an dan al-Hadits dapat diterapkan dalam segala kegiatan ekonomi pada lembaga ekonomi syari'ah.

\footnotetext{
${ }^{4}$ Moh.Ali Aziz, Ilmu Dakwah ( Jakarta : Kencana, 2004), hlm. 4.

${ }^{5}$ M. Munir, Wahyu Ilaihi, Manajemen Dakwah ( Jakarta : Prenadamedia Group,2006), hlm. 2.

${ }^{6}$ Wahidin Saputra, Pengantar Ilmu Dakwah (Jakarta : PT. Raja Grafindo Persada, 2012), hlm. 4.
}

Salah satu perbankan syariah yang terkenal dan mengalami perkembangan yang sangat pesat adalah Bank BNI Syariah. Hal ini ditandai dengan banyaknya prestasiprestasi yang diraih selama 2 Tahun belakangan ini, terutama tahun 2016. Diantara prestasi yang diraih yaitu sebagai "Most Efficient Bank Kategori Bank Syariah Tahun 2016 dan sebagai Peringkat ke-1 Kategori Good Corporate Governance 2 tahun berturut-turut yaitu tahun 2015 dan tahun 2016 serta merupakan Bank yang berhasil mempertahankan predikat kinerja sangat bagus 5 tahun berturut-turut. Disamping itu, dalam bidang manajemen pemasaran Bank BNI Syariah juga meraih berbagai prestasi dianataranya sebagai "The Most Efficient Bank Kategori Bank Syariah Aset di atas 10 T Tahun 2016 dan Peringkat ke-1 Marketing tahun 2015.

Selanjutnya, di Kota Pekanbaru terdapat Kantor Cabang Bank BNI Syariah, yaitu BNI Syariah Pekanbaru yang terletak di Jl. Sudirman No. 484 Pekanbaru. Bank BNI Syariah pekanbaru ini juga meraih prestasi yang gemilang yaitu sebagai "The Best 1 Champion WOW Service Excellence Award 2015 Pekanbaru Category : Islamic Bank". ${ }^{8}$ Menurut Aulia Eka A. selaku SME Consultant Officer pada bagian Pemasaran Bank BNI Syariah Pekanbaru ini mengatakan bahwa prestasi tersebut diraih karena Bank BNI Syariah ini senentiasa menerapkan nilai-nilai dakwah atau nilai syariah terutama prinsip Good Corporate Governance dalam setiap aktivitas ekonominya termasuk manajemen pemasaran. ${ }^{9}$

Jenis penelitian ini adalah deskriptif, sedangkan pendekatan yang digunakan dalam adalah pendekatan kualiatif yaitu

7 Prestasi Bank BNI Syariah dalam http://www.bnisyariah.co.id/awards, (diakses tanggal 05 November 2016).

${ }^{8}$ Prestasi Bank BNI Syariah Pekanbaru dalam http://www.bnisyariah.co.id/en/bni-syariah-kantorcabang-syariah-pekanbaru-mendapatkan-award, (diakses tanggal 05 November 2016).

9 Wawancara dengan Aulia Eka A. selaku SME Account Officer, pada tanggal 08 November 2016. 
penelitian yang bertujuan untuk menggambarkan, meringkas berbagai kondisi, berbagai situasi, atau berbagai fenomena realitas sosial yang ada di masyarakat yang menjadi objek penelitian, dan berupaya menarik realitas itu ke permukaan sebagai suatu ciri, karakter, sifat, model, tanda, atau gambaran tentang kondisi, situasi ataupun fenomena tertentu. ${ }^{10}$

\section{Implementasi Nilai-Nilai Dakwah dalamManajemen Pemasaran}

Secara sederhana nilai diartikan sebagai sesuatu yang berharga atau dianggap penting. ${ }^{11}$ Selanjutnya dalam Kamus Bahasa Indonesia Kontemporer nilai dapat diartikan sebagai hal-hal atau sifat-sifat yang bermanfaat atau penting untuk kemanusiaan. Jika dikaitkan dengan budaya berarti konsep abstrak sehubungan dengan masalah dasar yang bernilai dan sangat penting untuk kemanusiaan. Jika dikaitkan dengan agama maka berarti konsep tentang penghargaan suatu warga masyarakat terhadap masalahmasalah pokok dalam kehidupan beragama yang suci sehingga merupakan pedoman bagi tingkah laku keagamaan warganya. ${ }^{12}$

Selanjutnya Syamsul Munir Amin menegaskan bahwa nilai adalah aturan pandangan dan anggapan masyarakat, yang digunakan sebagai pedoman dalam menilai sesuatu dan dalam mengendalikan serta memilih tingkah laku dalam kehidupan sehari-hari.Jika nilai satu dengan nilai lainnya di satukan, maka di sebut dengan tata nilai, yaitu kumpulan nilai-nilai atau normanorma yang diakui oleh masyarakat, dan digunakan sebagai pedoman dalam menentukan realitas yang ada di

\footnotetext{
${ }^{10}$ Burhan Bungin, Penelitian Kualitatif( Jakarta : Kencana, 2007), hlm. 68.

${ }^{11}$ Tim Penyusun Pusat Bahasa Departemen Pendidikan Nasional, Kamus Besar Bahasa Indonesia : Edisi Ketiga,Hlm. 783.

${ }^{12}$ Peter Salim, Yenny Salim, Kamus Bahasa Indonesia Kontemporer (Jakarta : Modern English Press, 1995), hlm. 1035.
}

sekelilingnya, dan dalam menentukan sikap selanjutnya. ${ }^{13}$

Syamsul Munir Amin menyebutkan bahwa nilai terbagi menjadi beberapa macam atau kategori, diantaranya :Pertama, nilai etis yang mendasarkan orientasinya pada ukuran baik atau buruk.Kedua, nilai pragmatis, yang mendasarkan orientasinya pada ukuran berhasil atau gagal. Ketiga, nilai affek sensoris, yang mendasarkan orientasinya pada ukuran menyenangkan atau menyedihkan.Keempat, nilai religius, yang mendasarkan orientasinya pada ukuran halal atau haram, dosa atau tidak dosa. ${ }^{14}$ Nilai religius juga diartikan sebagai nilainilai yang terkandung dalam al-Qur'an dan al-Hadits.

Menurut Branston dan Stafford, nilainilai yang terdapat dalam institusi merupakan nilai-nilai yang dapat menumbuhkan semangat dan perilaku semua orang yang terlibat dalam institusi sehingga mereka dapat menjalankan institusi secara professional. Nilai-nilai tersebut akan saling berbagi antara satu dengan lainnya ketika mereka berinteraksi. ${ }^{15}$

\section{Pengertian Manajemen Pemasaran}

Istilah manajemen pemasaran atau marketing management dapat dirumuskan sebagai kegiatan menganalisa, merencanakan, mengimplementasi dan mengawasi segala kegiatan (program), guna memperoleh tingkat pertukaran yang menguntungkan dengan pembeli sasaran dalam rangka mencapai tujuan organisasasi. $^{16}$

Menurut Philip Kotler, guru besar pemasaran dari Universitas Northwestern Amerika, manajemen pemasaran diartikan sebagai uraian (aktivitas) perencanaan, pelaksanaan dan pengawasan atas program-

${ }^{13}$ Syamsul Munir Amin, Rekonstruksi Pemikiran Dakwah Islam ( Jakarta: Amzah, 2008), hlm. 56.

${ }^{14}$ Syamsul Munir Amin, Rekonstruksi Pemikiran Dakwah Islam, hlm. 57.

${ }^{15}$ Abdul Basit, Filsafat Dakwah, ( Jakarta: PT. Raja Grafindo Persada, 2013), hlm. 211.

${ }^{16}$ Buchari Alma, Manajemen Pemasaran dan Pemasaran Jasa, ( Bandung: Alfabeta, 2014), hlm. 130. 
program yang dirancang untuk menghasilkan transaksi pada target pasar, guna memenuhi kebutuhan perorangan atau kelompok berdasarkan asas saling menguntungkan, melalui pemanfaatan produk, harga, promosi, dan distribusi. ${ }^{17}$ Dari pengertian diatas dapat disimpulkan bahwa manajemen pemasaran ialah proses merencanakan, pengarahan dan pengawasan seluruh kegiatan pemasaran perusahaan untuk mencapai tujuanperusahaan. Penulis lebih memfokuskan pada proses atau kegiatan inti dari pemasaran itu sendiri, yang meliputi proses penetapan atau pemilihan produk, proses penetapan harga, proses distribusi dan proses promosi.

a) Proses Penetapan / Pemilihan
Produk
W.J Stanton menjelaskan bahwa produk ialah seperangkat atribut baik berwujud maupun tidak berwujud, termasuk didalamnya masalah warna, harga, nama baik pabrik, nama baik toko yang menjual (pengecer), dan pelayanan pabrik serta pelayanan pengecer, yang diterima oleh pembeli guna memuaskan keinginannya. Produk terdiri atas barang, jasa, pengalaman, events, orang, tempat, kepemilikan, organisasi, informasi dan ide. ${ }^{18}$

Jadi produk itu bukan hanya berbentuk sesuatu yang berwujud saja, seperti makanan, pakaian, dan sebagainya.Akan tetapi juga sesuatu yang tidak berwujud seperti pelayanan jasa.Semua diperuntukkan bagi pemuasan kebutuhan dan keinginan (need and wants) dari konsumen.

Proses penciptaan, penetapan atau pemilihan produk merupakan salah satu kegiatan penting dalam manajemen pemasaran dalam suatu perusahaan. Oleh karena itu, dalam proses penetapan atau penciptaan produk, Perusahaan harus mampu menciptakan suatu produk yang mampu memenuhi kebutuhan dan keinginan konsumen serta yang mampu memberikan

\footnotetext{
${ }^{17}$ Muhammad Ismail Yusanto, Muhammad Karebet Widjajakusuma, Menggagas Bisnis Islami (Jakarta : Gema Insani Press, 2002), hlm. 163.

${ }^{18}$ Buchari Alma, Manajemen Pemasaran dan Pemasaran Jasa, hlm. 139.
}

kepuasan paling tinggi terhadap konsumen. Produk yang berkualitas tinggi akan mampu memberikan kepuasan lebih tinggi kepada konsumen. ${ }^{19}$

b) Proses Penetapan Harga

Harga merupakan jumlah uang yang

harus dibayarkan konsumen untuk mendapatkan suatu produk guna memenuhi kebutuhan dan keinginan yang belum terpuaskan. $^{20}$ Buchari Alma mengatakan $^{2}$ bahwa pengertian harga memiliki kesamaan dengan istilah utility dan nilai. Yang dimaksud dengan utility ialah suatu atribut yang melekat pada suatu barang, yang memungkinkan barang tersebut, data memenuhi kebutuhan (needs), keinginan (wants) dan memuaskan konsumen (satisfaction). Sedangkan nilai (value) adalah nilai suatu produk untuk ditukarkan dengan produk lain. ${ }^{21}$

Dalam menentukan kebijakan harga dari suatu produk yang dihasilkan tentunya perlu memperhatikan dan mempertimbangkan secara seksama unsurunsur yang berkaitan dengan bauran harga yang terdiri dari: daftar harga, rabat, potongan tunai, jangka pembayaran, dan syarat kredit. Selain itu faktor-faktor yang perlu dipertimbangkan dalam suatu penetapan harga antara lain biaya, keuntungan, harga yang ditetapkan oleh pesaing dan perubahan keinginan pasar. Disamping unsur-unsur bauran harga diatas maka didalam penetapan harga, perusahan juga harus memperhatikan nilai dan manfaat dari produk yang dihasilkan guna memenuhi kebutuhan dan keinginan konsumen. ${ }^{22}$ Penetapan harga seyogyanya dilakukan setelah perusahaan memonitor harga yang ditetapkan pesaing agar harga yang ditentukan kompetitif, tidak terlalu tinggi atau sebaliknya. Dalam kenyataan sehari-hari

\footnotetext{
${ }^{19}$ M. Nur Rianto Al Arif, Dasar-dasar Pemasaran Bank Syariah ( Bandung : Alfabeta, 2012), hlm. 8.

${ }^{20}$ Marius P. Angipora, Dasar-dasar

Pemasaran, hlm. 26.

${ }^{21}$ Buchari Alma, Manajemen Pemasaran dan

Pemasaran Jasa, hlm. 169.

${ }^{22}$ Marius P. Angipora, Dasar-dasar

Pemasaran, hlm. 27.
} 
seringkali kebijakan penetapan harga yang ditentukan oleh pihak produsen ditetapkan dalam 2 (dua) cara, yaitu :harga eceran dan harga grosier. ${ }^{23}$

\section{c) Proses Distribusi}

Proses distribusi menunjukkan berbagai kegiatan yang dilakukan oleh produsen untuk menjadikan suatu produk yang dihasilkan dapat diperoleh dan tersedia bagi konsumen pada waktu dan tempat yang tepat dimana pun konsumen berada. ${ }^{24}$

Oleh karena itu, di dalam penetapan saluran distribusi, produsen atau perusahaan hendaknya memperhatikan unsur-unsur yang terkait dalam bauran distribusi yang terdiri dari : Sistem saluran, daya jangkau, lokasi, persediaan dan transportasi. Dengan memperhatikan unsur-unsur yang terkait dalam bauran distribusi tersebut, maka melalui kegiatan distribusi terhadap produkproduk yang dihasilkan, produsen atau perusahaan mengharapkan bahwa, melalui aktivitas tersebut, Produsen atau perusahaan mampu; Pertama, menciptakan nilai tambah produk melalui salah satu fungsi pemasaran yang mampu melaksanakan kegunaan bentuk, waktu, tempat dan pemilikan.Kedua, memperlancar arus saluran distribusi fisik dan non fisik yaitu aliran-aliran kegiatan yang terjadi antara lembaga-lembaga saluran yang terlibat di dalam proses pemasaran.

Dengan demikian produsen atau perusahaan harus mampu memilih, menetapkan dan mengatur secara tepat guna sistem saluran distribusi yang digunakan. Disamping itu secara berkala dan berkelanjutan, perusahaan perlu melakukan pengawasan untuk mencegah kelebihan tingkat persediaan, penyimpangan produk pada setiap tingkat saluran serta mengatur kegiatan pengangkutan produk secara efisien dan efektif guna menciptakan kegiatan distribusi yang menguntungkan. ${ }^{25}$

\footnotetext{
${ }^{23}$ Muhammad Ismail Yusanto, Muhammad Karebet Widjajakusuma, Menggagas Bisnis Islami, hlm. 173.

${ }^{24}$ Marius P. Angipora, Dasar-dasar Pemasaran, hlm. 27

${ }^{25}$ Marius P. Angipora, Dasar-dasar Pemasaran, hlm. 28.
}

d) Proses Promosi
Promosi merupakan komponen yang dipakai untuk memberitahukan dan mempengaruhi pasar bagi produk perusahaan, sehingga pasar dapat mengetahui tentang produk yang diproduksi oleh perusahaan tersebut.Adapun kegiatan yang termasuk dalam aktivitas promosi adalah periklanan, personal selling, promosi penjualan dan publisitas. Promosi di sini terkait dengan besaran biaya promosi dan kegiatan promosi yang akan di lakukan. Tujuan yang diharapkan dari promosi adalah konsumen dapat mengetahui tentang produk tersebut dan pada akhirnya memutuskan untuk membeli produk tersebut. ${ }^{26}$ Jadi tujuan utama kegiatan promosi ini adalah untuk menginformasikan, membujuk, mempengaruhi dan mengingatkan konsumen agar membeli produk yang dihasilkan.

\section{Perbankan Syariah}

Pada hakikatnya perbankan syariah diartikan sebagai segala sesuatu yang menyangkut tentang Bank Syariah dan Unit Usaha Syariah (UUS), mencakup kelembagaan, kegiatan usaha, serta cara dan proses dalam melaksanakan kegiatan usahanya. $^{27} \quad$ Selanjutnya, Kramen Perwaatmadja dan Muhammad Syahpantonio dalam buku nya Apa dan Bagaimana Bank Islam menjelaskan bahwa Bank Islam (Syariah) adalah bank yang dalam beroperasinya itu mengikuti ketentuanketentuan syariah Islam khususnya yang menyangkut tatacara bermuamalat secara Islam.

Dalam Undang-undang Nomor 21 Tahun 2008 tentang Perbankan Syariah dijelaskan bahwa fungsi dari Bank Syariah itu adalah sebagai lembaga intermediasi (Intermediary Institusion), yaitu menghimpun dana dari masyarakat dan menyalurkan kembali dana-dana tersebut kepada masyarakat yang membutuhkannya dalam bentuk pembiayaan. Disamping itu

\footnotetext{
${ }^{26}$ M. Nur Rianto Al Arif, Dasar-dasar

Pemasaran Bank Syariah, hlm. 16.

${ }^{27}$ Abu Muhammad Dwiono Koesen Al Jambi, Ayo ke Bank Syariah ( Jakarta : Pustaka Ar Rayhan, 2016), hlm. 4.
} 
keberadaan Bank Syariah di tengah-tengah perbankan konvensional adalah untuk menawarkan sistem perbankan alternatif bagi masyarkat yang membutuhkan layanan jasa perbankan tanpa harus khawatir atas persoalan bunga. ${ }^{28}$

Perbankan Syariah sebagai lembaga ekonomi Syariah yang mengacu pada alQur'an dan al-Hadits, maka ada empat prinsip utama yang senentiasa mendasari jaringan kerja perbankan syariah, diantaranya ; Pertama, perbankan non riba. Kedua, perniagaan halal dan tidak haram. Ketiga, keridhaan pihak-pihak dalam berkontrak. Keempat, pengurusan dana yang amanah, jujur dan bertanggung jawab. ${ }^{29}$

Untuk menjamin operasi Bank Islam tidak menyimpang dari tuntunan Syariah maka pada setiap Bank Syariah mengangkat manager dan pimpinan bank yang menguasai prinsip muamalah Islam. Selain dari pada itu, pada Bank Syariah dibentuk Dewan Pengawas Syariah, yaitu suatu Dewan yang sengaja dibentuk untuk mengawasi jalannya Bank Syariah sehingga senentiasa sesuai dengan prinsip Muamalah dalam Islam.Perbedaan prinsip manajemen anat ara Bank Syariah dengan Bank Konvensional dalam mengharmonisasikan kepentingan penyandang dana, pemegang saham, dan pemakai dana ialah sebagai berikut :

Pada Bank Konvensional kepentingan penyandang dana adalah diperolehnya imbalan berupa imbalan berupa bunga simpanan yang tinggi, sedangkan kepentingan pemegang saham adalah diperolehnya spread yang optimal antara suku bunga simpanan dan suku bunga pinjaman (mengoptimalkan interest difference). Dilain pihak kepentingan pemakai dana adalah biaya yang lebih murah berupa tingkat bunga yang rendah. Dengan demikian terhadap ketiga kepentingan tersebut sulit diharmonisaikan'. Sedangkan pada Bank Syariah kepentingan penyandang

\footnotetext{
${ }^{28}$ Trisadini P. Usanti, Abd. Shomad, Transaksi Bank Syariah (Jakarta : PT Bumi Aksara, 2013), hlm. 3 .

${ }^{29}$ Trisadini P. Usanti, Abd. Shomad, Transaksi Bank Syariah, hlm. 3.
}

dana, pemegang saham, dan pemakai dana dapat diharmonisasikan karena dengan sistem bagi hasil, kepentingan ketiga pihak tersebut parallel yaitu memperoleh imbalan bagi hasil sesuai dengan keadaan yang benarbenar terjadi. Manajemen bank akan berusaha mengoptimalkan keuntungan pemakai dana. ${ }^{30}$

\section{Nilai-nilai Dakwah Islam dalam Manajemen Pemasaran Syariah}

Sebagaimana telah dijelaskan bahwa jika pengertian nilai dikaitkan dengan dakwah maka akan dikenal dengan nilai dakwah yakni nilai-nilai Islam yang bersumber dari al-Qur'an dan al-Hadits. ${ }^{31}$ Nilai-nilai dakwah bukanlah suatu 'barang yang mati', melainkan nilai dinamis yang disesuaikan dengan semangat zaman dan perkembangan ilmu pengetahuan yang ada di masyarakat. Pada hakikatnya aktivitas dakwah Islam bertujuan untuk menyebarkan nilai-nilai ajaran Islam yang terkandung dalam al-Qur'an dan al-Sunnah serta meningkatkan pemahaman keagamaan dalam berbagai aspekajarannya agar diaktualisasikan dalam bersikap, berfikir dan bertindak. ${ }^{32}$ Untuk mewujudkan hal tersebut, seorang da'i perlu mengimplementasikan nilai-nilai dakwah dalam dirinya sehingga pesan-pesan yang akan disampaikannya berjalan sesuai dengan apa yang diharapkan. Jadi dapat dipahami bahwa nilai-nilai dakwah ialah pandangan yang paling penting atau dasar dalam sebuah aktivitas dakwah yang dilakukan secara sadar dalam rangka menyampaikan pesan-pesan ajaran Islam kepada orang lain agar mereka menerima dan menjalankan nilai-nilai dakwah yang telah disampaikan tadi yang bersumber pada alQur'an dan al-Sunnah. ${ }^{33}$

\section{${ }^{30}$ Kramen Perwaatmadja, Muhammad} Syahpantonio, Apa dan Bagaimana Bank Islam, hlm. 8.

${ }^{31}$ Abdul Basit, Filsafat Dakwah, hlm. 211.

${ }^{32}$ M. Munir, S.Ag, M.Ag, Wahyu Ilaihi, S.Ag, M.A, Manajemen Dakwah ( Jakarta : Prenadamedia Group,2006), hlm. 2.

${ }^{33}$ Skripsi Muhammad Ikhwan ,Nilai-nilai Dakwah Islam dalam Ideologi Partai Keadilan 
Sementara itu syariah marketing atau pemasaran syariah merupakan bisnis yang disertai dengan keikhlasan semata-mata hanya untuk mencari keridhaan Allah. Disamping itu, dalam syariah marketing, perusahaan tidak hanya berorientasi pada keuntungan semata, namun turut pula berorientasi pada tujuan lainnya yaitu keberkahan. Jadi manajemen pemasaran syariah merupakan aktivitas manajerial yang berhubungan dengan pemasaran yang dalam keseluruhan prosesnya tidak ada yang bertentangan dengan prisip dan aturan syariat. Setiap langkah, aktivitas, dan kegiatannya selalu selalu seiring dengan bisikan nurani, tidak akan ada lagi hal-hal yang bertentangan dengan hati nurani. Dengan kata lain dalam manajemen pemasaran Syariah senentiasa menerapkan nilai-nilai ajaran dakwah Islam yang bersumber dari al-Qur'an dan al-Hadits dalam setiap aktivitasnya, sehingga setiap kegiatan Syariah marketing tidak menyimpang dari ajaran-ajaran Islam.

Ada beberapa nilai-nilai dakwah Islam dalam manajemen pemasaran syariah yang mengambil konsep dari keteladanan sifat Rasulullah Saw, yaitu Shiddiq, Amanah, Fathanah, Tabligh dan Istiqamah. ${ }^{34}$

\section{a) Shiddiq.}

Yaitu memiliki kejujuran dan selalu melandasi ucapan, keyakinan, serta perbuatan berdasarkan ajaran Islam. Tidak ada satu ucapan pun yang saling bertentangan dengan perebutan. Allah Swt senantiasa memerintahkan kepada setiap orang beriman untuk memiliki sifat Shiddiq dan menciptakan lingkungan yang Shiddiq. Di dalam al-Qur'an kata shiddiq disebut sebanyak 154 kali.Beberapa diantaranya dimuat dalam QS. Ali Imran (3) : 15-17, AnNisa' (4) : 69, Al-Maidah (5) : 119, dan lainlain. Ini menandakan pentingnya sikap

Sejahtera Kota Pekanbaru ( Mahasiswa Manajemen Dakwah, UIN SUSKA RIAU, 2013), hlm. 11.

${ }^{34} \mathrm{M}$. Nur Rianto Al Arif, Dasar-dasar Pemasaran Bank Syariah, hlm. 19.
Shidiq bagi perilaku manusia dalam kehidupan sehari-hari. $^{35}$

Jujur merupakan sarana mutlak untuk mencapai kebaikan tatananmasyarakat. Oleh karenanya, shiddiq bukan sekedar wacana pribadi (untuk individu), tapi wacana publik, yaitu perlunya sebuah sistem dan struktur pengelolaan sesuatu yang jujur. Dalam manajemen pemasyaran syariah, seorang pemasar sekalipun tidak boleh melakukan kebohongan atau terlalu melebihlebihkan atas produk yang dijual hanya demi mengejar target penjualan. Dalam pemasaran syariah seperti pada perbankan syariah, antara nasabah dan pihak perusahaan atau lembaga merupakan mitra sejajar sehingga pihak lembaga bank memperlakukan nasabah seakan-akan sebagai saudaranya sendiri. Hal ini akan berimplikasi bahwa segala saran terkait dengan perencanaan keuangan nasabah didasari pada prinsip saling percaya dan bertujuan untuk memberdayakan nasabah dan bukan memperdaya nasabah.

Dalam kerja dan usaha kejujuran ditampilkan dalam bentuk kesungguhan dan ketetapan baik ketetapan waktu, janji, pelayanan, pelaporan, mengakui kelemahan serta kelebihan produk untuk kemudian dilakukan perbaikan terhadapnya. Dan menjauhkan diri dari perbuatan bohong dan menipu. ${ }^{36}$

\section{b) Fathanah.}

Yaitu mengerti, memahami, dan menghayati secara mendalam segala hal yang terjadi dalam tugas dan kewajiban. Fathanah berkaitan dengan kecerdasan, baik kecerdasan rasio, rasa, maupun kecerdasan ilahiyah. Fathanah juga menekankan kecerdasan emosional dan spiritual. Seorang pemasar di bank syariah dan lembaga ekonomi non bank syariah lainnya harus paham tentang seluruh produk yang ditawarkan, termasuk kaidah fiqhnya secara dasar. Sifat ini akan menumbuhkan kreativitas dan kemampuan untuk melakukan berbagai macam inovasi yang bermanfaat.

\footnotetext{
${ }^{35}$ M. Nur Rianto Al Arif, Dasar-dasar Pemasaran Bank Syariah, hlm.25.

${ }^{36} \mathrm{M}$. Nur Rianto Al Arif, Dasar-dasar

Pemasaran Bank Syariah, hlm. 26.
} 
Sumber daya manusia dalam industri perbankan syariah terutama yang berada di front linier harus mengerti mengenai seluruh aspek yang terkait dengan lembaga tersebut sebab merekalah yang menjadi ujung tombak perusahaan baik di dalam maupun di luar perusahaan. Masyarakat menjadi sasaran dakwah perusahaan dalam mengembangkan ekonomi syariah, apabila ekonomi syariah dapat semakin berkembang dan diterima di masyarakat maka akan menyebabkan kenaikan jumlah nasabah. ${ }^{37}$

Sifat fathanah yang merupakan perpaduan antara pengetahuan ('alim) dan hafalan (hafidz) telah berhasil meletakkan Nabi yusuf a.s dan timnya berhasil membangun Mesir, Allah SWT berfirman :

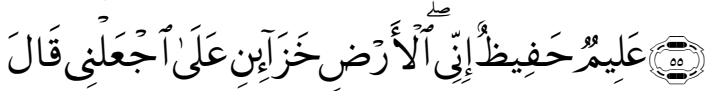

Artinya: 'Berkata Yusuf :'Jadikalanlah Aku bendaharawan Negara (Mesir),Sesungguhnya Aku adalah orang yang pandai menjaga, lagi berpengetahuan", (QS. Yusuf : 55) ${ }^{38}$

Sifat fathanah pula yang mengantarkan Nabi Muhammad Saw (sebelum di angkat menjadi Nabi) mendapat kan keberhasilan dalam perniagaan yang dilakukannya. Keterampilan dan keahlian yang dimiliki oleh Rasulullah Saw dalam berdagang menjadikannya seorang manajer pemasaran yang handal dari industri perdagangan Siti Khadijah.

c) Amanah.

Yaitu memiliki makna tanggung jawab dalam melaksanakan setiap tugas dan kewajiban. Amanah ditampilkan dalam keterbukaan, kejujuran, pelayanan prima dan ihsan (berupaya menghasilkan yang terbaik) dalam segalah hal. Sifat amanah harus dimiliki oleh setiap mukmin apalagi yang memiliki pekerjaan terkait dengan pelayanan kepada masyarakat. Seorang mukmin ketika

\footnotetext{
${ }^{37}$ M. Nur Rianto Al Arif, Dasar-dasar

Pemasaran Bank Syariah, hlm. 26.

${ }^{38}$ Departemen Agama Republik Indonesia, alQur'an dan Terjemahnya, hlm. 357.
}

mendapatkan amanah akan berupaya melaksanakan dengan sebaik-baiknya. ${ }^{39}$

Sifat amanah mementingkan tanggung jawab yang sangat hakiki dalam hubungannya dengan umat manusia, yang selalu yakin bahwa ada yang selalu mengawasi pelaksanaan tugasnya. Dalam Islam diyakini bahwa setiap tindak-tanduk kita selalu dalam pengawasan malaikat yang senentiasa mencatat kebaikan dan keburukan manusia.Dalam konteks ini lah amanah berkiprah. Allah SWT berfirman :

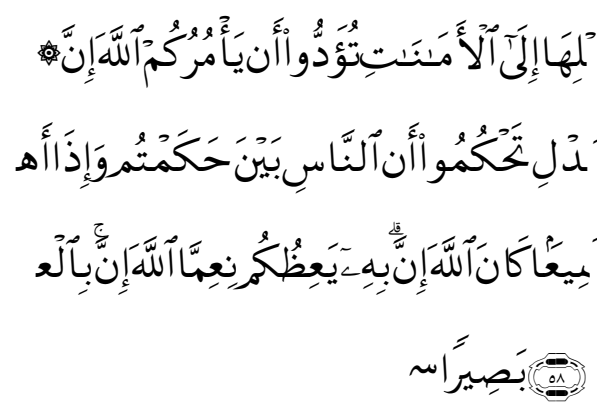

Artinya: 'Sesungguhnya Allah menyuruh kamu menyumapikan amanat kepada yang berhak menerimanya, dan (menyuruh kamu) apabila menetapkan hukum diantara manusia supaya kamu menetapkan dengan adil.Sesungguhnya Allah member pengajaran yang sebaik-baiknya kepadamu.Sesungguhnya Allah adalah Maha mendengar lagi Maha melihat'" (QS. An-Nisa' : $58)^{40}$

\section{d) Tabligh.}

Yaitu artinya mengajak sekaligus memberikan contoh kepada pihak lain untuk melaksanakan ketentuan-ketentuan ajaran Islam dalam setiap gerak aktivitas ekonomi yang dilakukan sehari-hari. Tabligh yang dengan hikmah, sabar, argumentative dan persuasive akan menumbuhkan hubungan kemanusiaan yang semakin solid dan kuat. Pada hakikatnya, tabligh ini berkaitan erat dengan risalah keislaman, yakni soal dakwah

\footnotetext{
${ }^{39}$ M. Nur Rianto Al Arif, Dasar-dasar

Pemasaran Bank Syariah, hlm. 27.

${ }^{40}$ Departemen Agama Republik Indonesia, alQur'an dan Terjemahnya, hlm. 128.
} 
dan penyampaian pesan-pesan keilahian. Tabligh mencakup semua aspek komunikasi dan interaksi sesama manusia. Tabligh selalu mengharapkan agar orang diajak berbicara bisa mengubah sikap dan tingkah lakunya agar sesuai dengan ayat-ayat kebesaran Allah SWT.

Seorang pemasar syariah harus memposisikan dirinya tidak hanya sebagai representasi dari perusahaan namun turut pula sebagai juru dakwah dalam pengembangan ekonomi syariah. Masih banyak masyarakat yang belum mengerti tentang ekonomi syariah, dan itulah yang menjadi tugas bagi seorang pemasar syariah untuk menjelaskan sekaligus menjual produk syariah yang akan ditwarkan kepada konsumen.

e) Istiqamah.

Yaitu artinya konsisten, hal ini memberikan makna seorang pemasar syariah dalam praktik pemasarannya selalu istiqamah dalam penerapan aturan syariah. Seorang pemasar syariah harus dapat dipegang janjinya, tidak diperkenankan seorang pemasar syariah berubah-ubah dalam memberikan janji. Sebab dalam suatu perusahaan syariah konsistensi dari seorang pemasarnya menjadi cermin dari perusahaan tersebut secara keseluruhan. ${ }^{41}$

Kelima nilai ini akan mampu melahirkan suatu turunan budaya kerja yang berbeda pada institusi keuangan syariah.

Dalam Pemasaran perlu didasari oleh Nilai-nilai yang terkandung dalam al-Qur'an dan al-Hadits Nabi, seperti nilai-nilai di atas. Salah satu ayat al-Qur'an yang dapat dijadikan pijakan dalam kegiatan pemasaran, yaitu Firman Allah SWT :

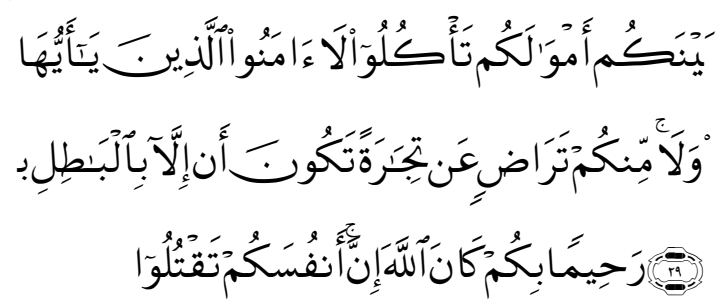

Artinya: 'Wahai orang-orang yang beriman! Janganlah kamu saling memakan

\footnotetext{
${ }^{41}$ M. Nur Rianto Al Arif, Dasar-dasar Pemasaran Bank Syariah, hlm. 28.
}

harta sesamamu dengan jalan bathil (tidak benar), kecuali dalam perdagangan yang berlaku atas dasar suka sama suka di antara kamu. Dan janganlah kamu membunuh dirimu.Sungguh, Allah Maha penyanyang kepadamu.( QS. An-Nisa' : 29$)^{42}$

\section{Kesimpulan}

Setelah data disajikan dan dianalisis, dapat disimpulkan bahwa implementasi nilai-nilai dakwah dalam manajemen pemasaran di Bank BNI Syariah Pekanbaru ini telah mengacu kepada nilai-nilai dakwah yang terkandung dalam aktivitas manajemen pemasaran Syariah pada umumnya yang mengambil konsep keteladanan dari sifat Rasulullah SAW, yang terdiri dari nilai Shiddiq, Fathanah, Amanah, Tabligh dan Istiqamah walau masih memerlukan pembenahan dan pengawasan yang efektif.

Kelima nilai tersebut telah diimplementasikan dalam setiap aktivitas manajemen pemasaran di Bank BNI Syariah Pekanbaru ini baik dalam proses pemilihan produk, penentuan harga, distribusi maupun proses promosi. Hal ini bertujun agar pelaksanaan manajemen pemasaran di Bank BNI Syariah Pekanbaru ini sesuai dengan prinsip-prinsip Syariah, sehingga eksistensi dan citra bank sebagai lembaga perbankan Syariah yang berdasarkan pada prinsipprinsip Syariah yang bersumber dari alQur'an dan al-Hadits tetap terjaga dengan baik. Implementasi nilai-nilai dakwah dalam manajemen pemasaran di Bank BNI Syariah Pekanbaru ini masih memerlukan pembenahan dan evaluasi agar pelaksanaannya dapat berjalan dengan baik dan benar-benar sesuai dengan prinsipprinsip Syariah yang bersumber dari alQur'an dan al-Hadits, tetapi secara global telah tersistem dan terlaksana dengan baik.

\section{Bibliografi}

${ }^{42}$ Departemen Agama Republik Indonesia, alQur'an dan Terjemahnya, hlm. 122. 
Al Arif, M. Nur Rianto, Dasar-dasar Pemasaran Bank Syariah, (Bandung: Alfabeta, 2012).

Alma,

Buchari,

ManajemenPemasarandanPemas aranJasa,

(Bandung

:Alfabeta,2014).

Amin, Munir,

Syamsul,

RekonstruksiPemikiranDakwah

Islam, (Jakarta : Amzah, 2008).

Angipora,P. Marius, Dasar-dasarPemasaran

: EdisiRevisi, (Jakarta : Raja GrafindoPersada, 2002).

Assauri, Sofjan, ManajemenPemasaran :Dasar, KonsepdanStrategi( Jakarta : PT. Raja GrafindoPersada, 1996).

Aziz, Moh.Ali, IlmuDakwah, ( Jakarta : Kencana, Cet.1, 2004).

Basit, Abdul, FilsafatDakwah, ( Jakarta : PT. Raja GrafindoPersada, 2013).

Bungin, M.Burhan, PenelitianKualitatif :Komunikasi, Ekonomi, KebijakanPublikdanIlmuSosialL ainnya (Jakarta:Prenada Media Group, 2007).

Departemen Agama Republik Indonesia, alQur'an danTerjemahnya( Semarang : PT. KaryaToha Putra Semarang, $\mathrm{tt}$ ).

Ikhwan,Muhammad , Nilai-nilai Dakwah Islam dalam Ideologi Partai Keadilan Sejahtera Kota Pekanbaru, (Pekanbaru : Skripsi, 2013).

Kasmir, ManajemenPerbankan( Jakarta : Rajawali Pers, 2012).

Muhammad, Abdu, Dwiono Koesen Al Jambi, Ayo ke Bank Syariah, (Jakarta : Pustaka Ar Rayhan, 2016).

Umam,

Khaerul, ManajemenPerbankanSyari'ah( Bandung : Pustaka Setia, 2013).

Nitisemito, S. Alex ,1.647 Dialog Bisnis dan Manajemen, (Jakarta : Ghalia Indonesia, 2001).

Munir. M, WahyuIlaihi, Manajemen Dakwah, (Jakarta : Prenada Media Group, 2006).
Perwaatmadja, Kramen , Muhammad Syahpantonio, Apa dan Bagaimana Bank Islam, (Yogyakarta : Dana Bhakti Wakaf, 1992).

Prestasi Bank BNI Syariah dalam http://www.bnisyariah.co.id/awa $\underline{r d s}$, (diakses tanggal 05 November 2016).

Prestasi Bank BNI Syariah Pekanbaru dalam http://www.bnisyariah.co.id/en/b ni-syariah-kantor-cabangsyariah-pekanbarumendapatkan-award, (diakses tanggal 05 November 2016).

P. Usanti, Trisadini, Abd. Shomad, Transaksi Bank Syariah, (Jakarta : PT Bumi Aksara, 2013).

Salim, Peter, Yenny Salim, Kamus Bahasa Indonesia Kontemporer, (Jakarta : Modern English Press, 1995).

Saputra, Wahidin, Pengantar Ilmu Dakwah, (Jakarta : PT. Raja Grafindo Persada, 2012).

Tim Penyusun Pusat Bahasa Departemen Pendidikan Nasional, Kamus Besar Bahasa Indonesia :Edisi Ketiga, ( Jakarta : Balai Pustaka, 2005).

Wawancara dengan Aulia Eka A. selaku SME Account Officer, pada tanggal 08 November 2016.

Yusanto, Muhammad Ismail, Muhammad Karebet Widjaja kusuma, Menggagas Bisnis Islami, (Jakarta :Gema Insani Press, 2002 